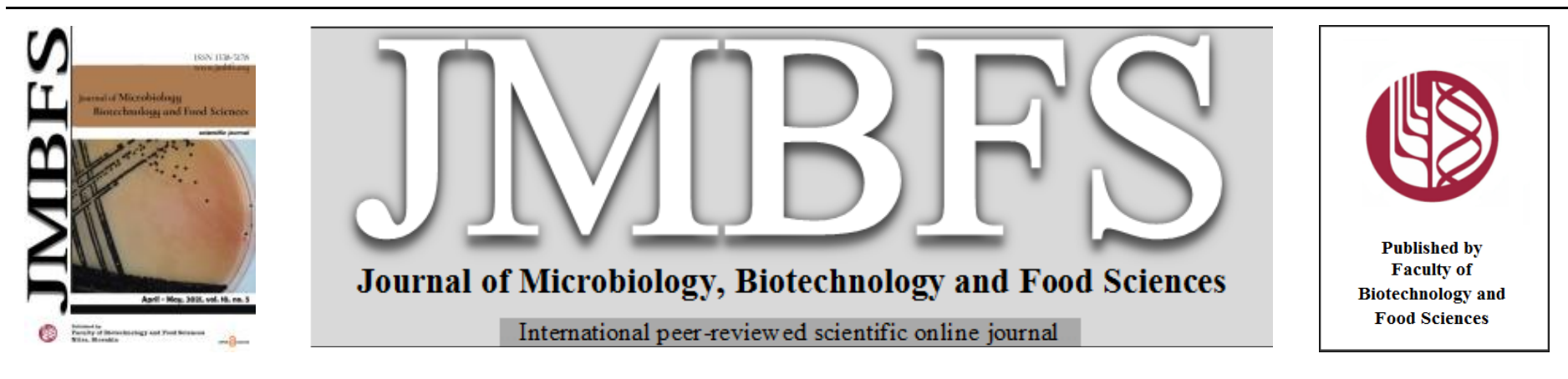

\title{
MILK ANALYSIS BY FLOW CYTOMETRY TO IDENTIFY SUBCLINICAL UDDER INFECTION
}

\author{
O. Molozhava ${ }^{2}$, V. Mazurenko ${ }^{1,2 *}$, I. Sobko $^{1}$, D. Kolibo $^{2,3}$ \\ $\operatorname{Address}(e s):$ \\ ${ }^{1}$ Veterinary Diagnostic Center, LTD, Kyiv, Ukraine. \\ ${ }^{2}$ NSC Institute of Biology and Medicine of the National Tarasa Shevchenko University, Kyiv, Ukraine. \\ ${ }^{3}$ Palladin Institute of Biochemistry of NAS, Department of Molecular Immunology Kyiv, Ukraine.
}

*Corresponding author: victoriamazurenkoo@gmail.com

https://doi.org/10.15414/jmbfs.3257

\section{ARTICLE INFO}

Received 11. 6. 2020

Revised 2. 11. 2020

Accepted 11. 11. 2020

Published 1. 4. 2021

Regular article

open $\odot$ access

\begin{abstract}
Subclinical mastitis in cows is an expensive disease that is difficult to detect without special tests for diagnosis. The number of somatic cells (SCC) in milk is used as an important indicator of the udder health since SCC are parts of the innate immune system and are involved in protecting the mammary glands from infection. Our study aimed to determine whether it is possible to detect subclinical mastitis in cattle at an early stage using a simple and fast flow cytometry method, and then to suggest the main cell populations on the point sections of flow cytometry and, together with that, to develop a method for predicting mastitis. As a result of the microscopic method, three samples with contagious infection were identified. It was shown that milk from cows with mastitis contained populations of cells accompanying inflammation (suspected macrophages, granulocytes) that can be detected using frontal light scattering (FS) and right signals (SS).
\end{abstract}

Keywords: subclinical mastitis, flow cytometric, cow's milk, somatic cells

\section{INTRODUCTION}

It is known that cattle milk is a valuable biological nutrient liquid consisting of water, protein, fats, carbohydrates, minerals (Dodenko et al., 2013). Other important components are somatic cells, presented in different proportions: leukocytes, neutrophils, macrophages, lymphocytes, epithelial cells (Proshutinskaya et al., 2019; Malik et al., 2018). The number of somatic cells (SCC) in milk is used as an important indicator of the udder health since SCC are parts of the innate immune system and are involved in protecting the mammary glands from infection (Podrez et al., 2017; Sharma et al., 2012). The quality and quantity of the above-mentioned cells are influenced by many factors such as the level of milk yield, lactation stage, as well as individual and environmental factors and conditions on the farm management (Vissio et al., 2018).

High level of somatic cells in milk is associated with inflammation of the udder, which leads to bacterial infections in the mammary gland, changes in milk composition, and downfall to lower grade milk ( $\mathbf{L i}$ et al., 2014). The development of an inflammation process in the mammary gland increases the number of neutrophils, which contain phagocytized bacterial cells (Rainard et al.,2006). Proper monitoring of SCC will reduce the percentage of clinical outbreaks of mastitis, which helps to avoid the culling of milk and cows (Sharma et al., 2011). Currently, four primary types of cells studied constituting SCC, namely macrophages, neutrophils, lymphocytes, and epithelial cells (Alhussien et al., 2016.). Macrophages are the predominant cell type in healthy cow's milk (Alhussien et al., 2018). In case of infection, the resident macrophages alarm of the danger, releasing cytokines and chemoattractant that attract neutrophils into the center, which, in turn, are quickly sent to the site of infection. When neutrophils arrive at the site of infection, they phagocytize microorganisms and carry out killing using a combination of oxidative and non-oxidative mechanisms (Quinn et al., 2011). Macrophages and neutrophils are active phagocytes that are capable of absorbing microbial cells and play an important role in the development of cellular responses of innate immunity. In addition, macrophages are involved in the development of specific adaptive immunity because they are able to activate lymphocytes (Pillai et al., 2001).

Lymphocytes play a central role in the implementation of specific reactions of the adaptive immune system. They can recognize foreign antigens by the antigenspecific membrane receptors in the invasion of pathogens (Alhussien et al., 2018). Also, in the composition of SCC epithelial cells of the mammary glands are detected, these are cells that produce milk (Quin et al., 2011). Modern methodical possibilities of flow cytometry during the last ten years allow new methods widely used for the analysis of milk samples with a high level of SCC and also samples of milk with a low content of SCC, analysis of which is the most technically difficult (Dosogne et al., 2003); (Koess et al., 2008). Thus, flow cytometry can automatically handle a substantially greater number of milk samples in comparison with normal cytology techniques and fluorescence microscopy (Sobti et al., 2003).

Death of milk somatic cells is a prerequisite for normal physiological development. Currently, at least three main types of cell death are distinguished: necrosis, apoptosis, and autophagy. Necrosis usually occurs in those cases when a cell is damaged so badly that it may no longer exist, but there is also a variant of / receptor-dependent control of necrosis (Motyl et al., 2007). Necrotic cells swelling, denaturation and coagulation of cytoplasmic proteins, destruction of cellular organelles, violation of the integrity of the plasma membrane, and exit of cellular contents outside are observed (Van Oostveldt et al., 2001).

Apoptosis can be part of the programmed ontogenetic processes, but also can be induced by various stimuli: DNA damage by ionizing radiation or chemical agents, heat and cold shock, cells reacting with cytotoxic lymphocytes, etc. (Van Oostveldt et al. 2002) The main function of autophagy is to maintain intercellular homeostasis. In the autophagic type of cell death, all the organelles of the cell are digested, leaving only cellular debris absorbed by macrophages (Motyl et al., 2007); (Sladek et al., 2001).

The aim of our study was to determine whether it is possible to detect subclinical mastitis in cattle at an early stage, using a flow cytofluorimetric method, and to develop a method for predicting mastitis.

\section{MATERIALS AND METHODS}

Animals

Twenty lactating Holstein cows were included in the current study, housed in different governmental farms within the territory of Ukraine. Diseased cows, and those affected with clinical mastitis, in early lactation and late pregnancy were excluded from the study.

\section{Milk sampling}

Samples were selected from 1 quarter randomly after California mastitis test. 50 ml samples of milk from cows $(n=20)$ were aseptically collected in sterile 
bottles, stored in the refrigerator at the temperature of $4^{\circ} \mathrm{C}$ and delivered to the laboratory for 4 hours while maintaining refrigerated conditions.

\section{Bacteriological examination}

To isolate aerobic bacteria from the studied milk samples, by their identification and determination of the type of hemolysis, blood agar produced by BioMerieux $^{\mathrm{tm}}$ (France) was used. For preliminary identification and selective isolation, we used mannitol salt agar (MSA) (as a selective and differential medium for the isolation of pathogenic staphylococci), Edwards agar (for the rapid isolation of Streptococcus agalactiae and other streptococci) manufactured by Himedia ${ }^{\text {tm }}$ (India) and Biolife ${ }^{\mathrm{tm}}$ (Italy). Staining bacterial preparations was performed according to Gram method (Thairuet al., 2014). Identification of the isolated bacterial isolates was carried out using commercial test systems STREPTOtest ${ }_{16}$ manufactured by ErbaLachema (Czech Republic). Cultural media and commercial test systems were cultured at a temperature of $37 \pm 1^{\circ} \mathrm{C}$ in an incubator for $18 \pm 2$ hours in an aerobic thermostat.

\section{Preparation of milk samples for flow cytometry}

For isolation of cells from milk, samples were centrifuged for 10 minutes at 180 $\times$ g. Fat layer and supernatant were removed with a cotton swab, test tube held upside down until they are thoroughly cleaned with a cotton swab to remove any grease adhering to the tube wall, to exclude debris carried microscopy in samples of cow`s milk on an automated cell counter Countess FL cells.

\section{Flow cytometry}

Milk samples were centrifuged for $15 \mathrm{~min}$ at $200 \times \mathrm{g}$ and a temperature of $4^{\circ} \mathrm{C}$, and the precipitate was suspended in phosphate buffered saline (PBS). Cell staining buffer $(\mathrm{CSB})$ was adjusted to $15 \mathrm{ml}$, centrifuged at $350 \times \mathrm{g}$ for 5 minutes. The precipitate was collected, $3 \mathrm{ml}$ of lysing buffer was added to each tube and kept on ice for 5 minutes. To determine the death path of cells isolated from milk we used the recombinant protein Annexin V labeled with a fluorescent label EGFP, which specifically interacts with phosphatidylserine and ethidium bromide $(\mathrm{EtBr})$, which is a fluorescence DNA intercalator with a maximum absorption wavelength of $520 \mathrm{~nm}$ and maximum fluorescence intensity of 600 $\mathrm{nm}$, which increases by 20 times when interacting with DNA. Cells have been pelleted by centrifugation at $300 \mathrm{xg}$ for $10 \mathrm{~min}$. Then, $500 \mathrm{ul}$ of medium $10 \mathrm{mM}$ HEPES, $150 \mathrm{mM} \mathrm{NaCl}, 5 \mathrm{mM} \mathrm{KCl}, 1 \mathrm{mM} \mathrm{MgCl} 2,1,8 \mathrm{mM} \mathrm{CaCl} 2$ was added to residue cells and supplemented with $10 \mu \mathrm{g}$ of recombinant Annexin V-EGFP and $6 \mu \mathrm{g} \mathrm{EtBr}$. The cell pellet was incubated for $15 \mathrm{~min}$ at room temperature and placed in an incubator at $4^{\circ} \mathrm{C}$. Samples were analyzed using a Coulter Epics XL flow cytometer (Beckman Coulter) with an argon laser (fixed excitation wavelength $-488 \mathrm{~nm}$ ) based on the use of the following parameters: direct (smal angular) FS scattering and side SS scattering, as well as fluorescence intensity from FL1 channels $(515-535 \mathrm{~nm})$ and FL3 $(610-630 \mathrm{~nm})$. Flow cytometry was adjusted to count up to 10,000 cells per sample. The percentage of cells of each type was calculated as its proportion to the total number of counted cells.

\section{Statistical analysis of data}

First, the graph data were analyzed using an FCS Express Shortcut. Then, the Mann-Whitney and Student's $t$ test for comparing values were applied. The statistical analyses were performed using Statistica statistical software version The results are reported as the mean \pm standard error, and significance was set at $\mathrm{P}>0.05$, t-test $=1.91$.

\section{RESULTS AND DISCUSSION}

Microscopic examination of milk samples from 20 cows has shown that somatic cells in the samples were presented in different quantities, from 24740 to 5494800 in $1 \mathrm{ml}$. In samples of milk, Streptococcus agalactiae (3 out of 20 samples) and Staphylococcus aureus (1 sample out of 20) bacteria were detected, which confirms intramammary infection. It is interesting that somatic cell count in the infected milk was the highest compared to the non-infected milk.

Table 1 The results of microscopic analysis of milk precipitate and bacteriological examination of milk secretion of cattle

\begin{tabular}{l|c}
\hline $\begin{array}{l}\text { The total number of cells in 1 } \\
\text { ml of milk }\end{array}$ & Bacteriological examination of milk \\
\hline 24740 & Negative result \\
\hline 27183 & Negative result \\
\hline 38460 & Negative result \\
\hline 46640 & Negative result \\
\hline 52600 & Negative result \\
\hline 55000 & Negative result \\
\hline 56860 & Negative result \\
\hline 59500 & Negative result \\
\hline 63700 & Negative result \\
\hline 87200 & Negative result \\
\hline 89400 & Negative result \\
\hline 87533 & Negative result \\
\hline 99833 & Negative result \\
\hline 100660 & Negative result \\
\hline 110800 & Negative result \\
\hline 121600 & Negative result \\
\hline 169567 & Negative result \\
\hline 177724 & Streptococcus agalactiae \\
\hline 280100 & Streptococcus agalactiae \\
\hline 549480 & Streptococcus agalactiae; \\
& Staphylococcus aureus \\
\hline
\end{tabular}

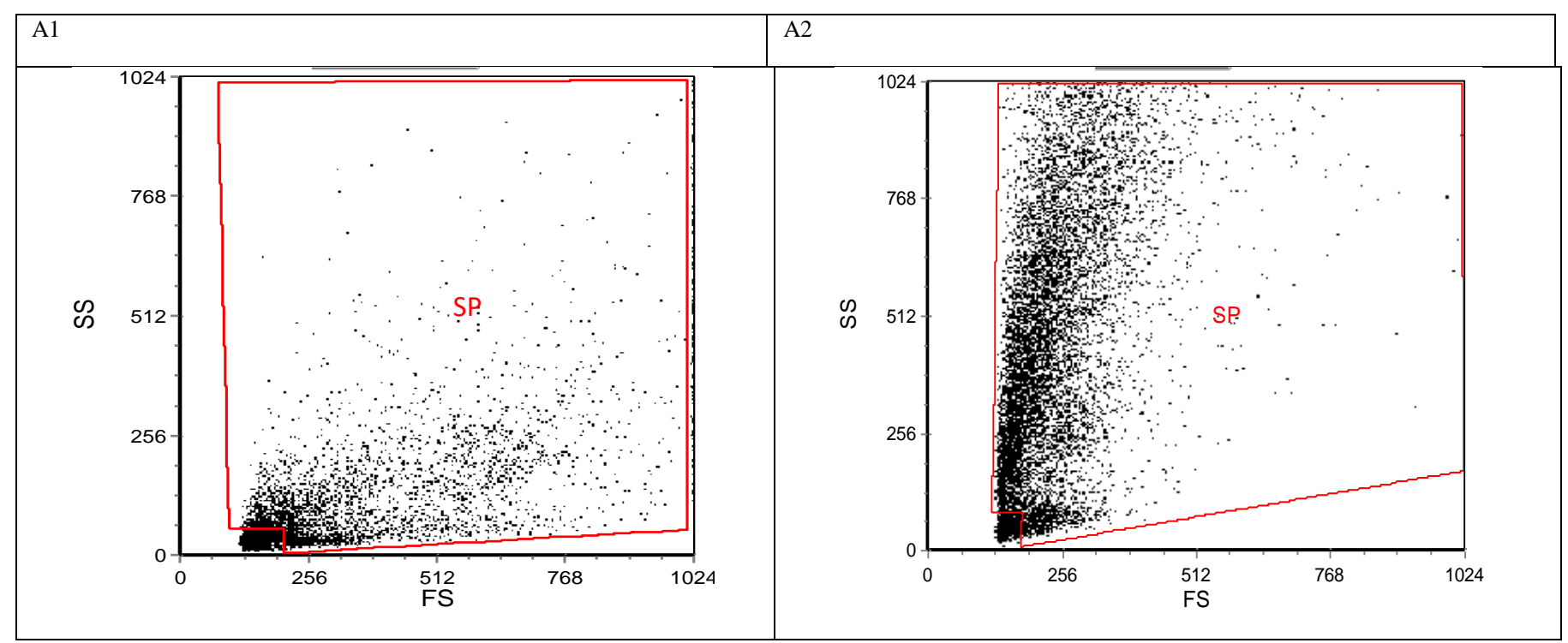

Figure 1 Characteristic of the milk samples collected from cows with subclinical mastitis and apparently healthy cows. Flow cytometry of milk cells isolated from cows (A1) with a low content of somatic cells (100,660 cells $/ \mathrm{mL})$ and with high somatic cells $(5494800$ cells/mL) (A2). Dot plot of SS versus FS. SP*standard population (gate) cells which analyzed by flow cytometric in order to excluded debris

Dairy industry currently considers quarters with $\mathrm{SCC}<200,000$ cells $/ \mathrm{ml}$ as an indicator of a healthy quarter (Malik, et al., 2018). As a result, our research, one sample of cow's milk with contagious infection were identified containing SCC with 177744 cells $/ \mathrm{mL}$ of milk. The cell populations present in milk change during the development of inflammation and mastitis. A heterogeneous population of cells may also be present in cows with a subclinical course of 
mastitis. Milk from cows with mastitis contained additional populations of cells accompanying inflammation (supposedly neutrophils), which can be detected by the cell distribution diagram by signals with frontal (FS) and lateral (SS) light scattering (Fig. 1).

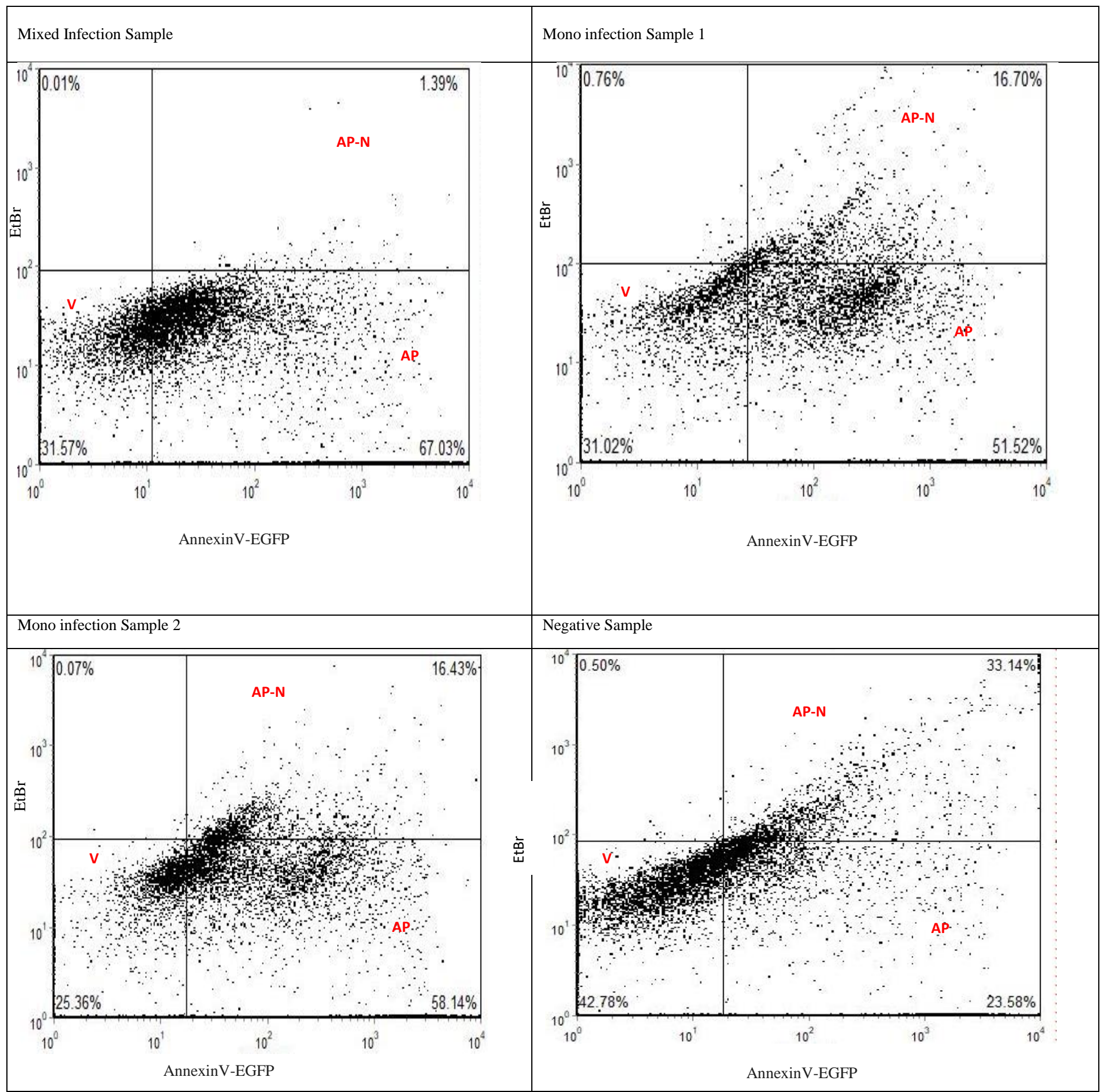

Figure 2 Graphs of a typical experiment for determining apoptosis and necrosis of milk cells with subclinical mastitis of cows, where V-living cells (EGFP- / EtBr -) are presented, V-AP cells (EGFP + / EtBr -) in early apoptosis; AP-N in late apoptosis (EGFP + / EtBr +) and cells during necrosis (EGFP- / EtBr +).

Changes in the plasma membrane of somatic milk cells are one of the earliest characteristics of the development of apoptosis detected in living cells. Normally, the outer and inner layers of the membrane differ significantly in their lipid composition, in particular, phosphatidylserine is absent in the outer layer of living membrane cells (Van Oostveldt et al., 2002). Externalization of phosphatidylserine is necessary for the cells of the mammary gland, as this is a kind of signal for macrophages in the secretion of the mammary gland involved in the absorption of apoptotic bodies (Van Oostveldt et al., 2001). The presence of phosphatidylserine in the outer membrane of apoptotic cells allows Annexin V-EGFP for counting the number of cells by cytofluorometry (Fig. 2). It has been shown that with a low content of cells in milk they predominantly die by apoptosis.

Necrotic cells SCC in a cow without mastitis was $24 \%$ compared to $67 \%$ in cows with mastitis. The number of apoptotic SCC in a cow without mastitis was $33 \%$ compared to $12 \%$ in cows with mastitis (Fig. 2). As a result, we can conclude that apoptosis is closely related to the functionality of neutrophils and macrophages (Van Oostveldt et al., 2002; Piepers et al., 2009) and plays a key role in the defense against invading pathogens and physiology of the inflammatory response (Boutet et al., 2004; Mehrzad et al., 2004). The viability of milk cells only slightly and reproducibly decreased at various stages of washing and centrifugation, which clearly excludes the possibility that the wide range of somatic cell viability observed in this study is caused by sample processing. These various studies suggest that the viability of milk cells varies and depends on the status of the infection (Boutet et al., 2004; Mehrzad et al., 2004), the start time of infection (Slàdek et al., 2005), as well as ratios and lactation (Van Oostveldt et al., 2001; Mehrzad et al., 2002).

A comparison of our results with the results of other studies should be undertaken with cautiously. We can conclude that our method offers the possibility of flow 
cytometric identification and quantification of viable, apoptotic, and necrotic milk somatic cells for the detection of latent mastitis in cows. But further studies are required to determination neutrophils and monocytes for intramammary infections because this information could prove useful, especially for evaluating cows in late lactation and just after freshening, when SCC may be elevated physiologically.

\section{CONCLUSIONS}

Apoptosis and necrosis of somatic cells make it possible to better assess the state of immune homeostasis, and that should be considered when diagnosing diseases. The determination of the number of events of phagocytes by the mammary gland of cows allows a more objective assessment of the state of local immunity of the udder in the norm and in the event of a pathology. Cell populations present in milk change during the development of inflammation and mastitis. A heterogeneous population of cells may also be present in cows with a subclinical course of mastitis. Flow cytometry of milk screening can serve as a diagnostic and prognostic criterion in monthly studies of all cows in the dairy herd to diagnose inflammation and predict the development of subclinical mastitis Correct cell monitoring can reduce the percentage of clinical outbreaks of mastitis, and help to avoid the culling of milk and cows.

\section{REFERENCES}

Alhussien, M., Manjari, P., Mohammed, S., Sheikh, A. A., Reddi, S., Dixit, S., \& Dang, A. K. (2016). Incidence of mastitis and activity of milk neutrophils in Tharparkar cows reared under semi-arid conditions. Tropical animal health and production, 48(6), 1291-1295. https://doi.org/10.1007/s11250-016-1068-8

Alhussien, M. N., \& Dang, A. K. (2018). Milk somatic cells, factors influencing their release, future prospects, and practical utility in dairy animals: An overview. Veterinary https//doi.org/10.14202/vetworld.2018.562-577

Boutet, P., Boulanger, D., Gillet, L., Vanderplasschen, A., Closset, R., Bureau, F., \& Lekeux, P. (2004). Delayed neutrophil apoptosis in bovine subclinical mastitis. Journal of dairy science, 87(12), 4104-4114 https://doi.org/10.3168/jds.S0022-0302(04)73553-5

Dodenko, O. V., \& Vistovskaya, V. P. (2013). Vliyaniye somaticheskikh kletok na lipoliticheskuyu aktivnost' i kachestvennyye pokazateli syrogo korov'yego moloka. Izvestiya Altayskogo gosudarstvennogo universiteta, 1 (3 (79)), 061-065 (in Russ.)

Dosogne H, Vangroenweghe F, Mehrzad J, Massart-Leën AM, Burvenich C (2003). Differential Leukocyte Count Method for Bovine Low Somatic Cel Count Milk. J. Dairy Sci. 86(3): 828-834. https://doi.org/10.3168/jds.S0022$\underline{0302(03) 73665-0}$

Koess, C., \& Hamann, J. (2008). Detection of mastitis in the bovine mammary gland by flow cytometry at early stages. Journal of Dairy Research, 75(2), 225232. https://doi.org/10.1017/S0022029908003245P

Li, N., Richoux, R., Boutinaud, M., Martin, P., \& Gagnaire, V. (2014). Role of somatic cells on dairy processes and products: a review. Dairy science \& technology, 94(6), 517-538. https://doi.org/10.1007/s13594-014-0176-3

Mehrzad, J., Duchateau, L., \& Burvenich, C. (2004). Viability of milk neutrophils and severity of bovine coliform mastitis. Journal of dairy science, 87(12), https://doi.org/10.3168/jds.S0022-0302(04)73558-4

Malik, T. A., Mohini, M., Mir, S. H., Ganaie, B. A., Singh, D., Varun, T. K., ... \& Thakur, S. (2018). Somatic cells in relation to udder health and milk quality-a review. J Anim Health Prod,6(1), 18-26. http://dx.doi.org/10.17582/journal.jahp/2018/6.1.18.26

Mehrzad, J., Duchateau, L., Pyörälä, S., \& Burvenich, C. (2002). Blood and milk neutrophil chemiluminescence and viability in primiparous and pluriparous dairy cows during late pregnancy, around parturition and early lactation. Journal of Dairy Science, 85(12), 3268-3276. https://doi.org/10.3168/jds.S00220302(02)74415-9

Motyl, T., Gajewska, M., Zarzynska, J., Sobolewska, A., \& Gajkowska, B. (2007). Regulation of autophagy in bovine mammary epithelial cells. Autophagy, 3(5), 484-486. https://doi.org/10.4161/auto.4491

Piepers, S., De Vliegher, S., Demeyere, K., Lambrecht, B. N., de Kruif, A., Meyer, E., \& Opsomer, G. (2009). Flow cytometric identification of bovine milk neutrophils and simultaneous quantification of their viability. Journal of dairy science, 92(2), 626-631. https://doi.org/10.3168/jds.2008-1393

Pillai, S. R., Kunze, E., Sordillo, L. M., \& Jayarao, B. M. (2001). Application of differential inflammatory cell count as a tool to monitor udder health. Journal of Dairy Science, 84(6), 1413-1420. https://doi.org/10.3168/jds.S00220302(01)70173-7

Podrez, V. N., Shlyakhtunov, V. I., Karpenya, M. M., Shamich, YU. V., Shaura, T. A., \& Bazylev, D. V. (2017). Kontrol' kachestva moloka.

Proshutinskaya, YU. S., \& Neverova, O. P. (2019). Somaticheskiye kletki v moloke korov kak pokazatel' yego kachestva. Molodezh' i nauka, (3), 84-84. (in Russ.)

Quinn, P. J., Markey, B. K., Leonard, F. C., Hartigan, P., Fanning, S., \& Fitzpatrick, E. (2011). Veterinary microbiology and microbial disease. John
Wiley \& Sons.

Rainard, P., \& Riollet, C. (2006). Innate immunity of the bovine mammary gland. Veterinary https://doi.org/10.1051/vetres:2006007 research, 37(3) $369-400$

Sharma, Neelesh, N. K. Singh, and M. S. Bhadwal. "Relationship of somatic cell count and mastitis: An overview." Asian-Australasian Journal of Animal Sciences 24.3 (2011): 429-438. https://doi.org/10.5713/ajas.2011.10233

Sharma, N., Rho, G. J., Hong, Y. H., Kang, T. Y., Lee, H. K., Hur, T. Y., \& Jeong, D. K. (2012). Bovine mastitis: an Asian perspective. Asian Journal of Animal and Veterinary Advances, 7, 454-476. DOI: 10.3923/ajava.2012.454.476 Sladek, Z., \& Rysanek, D. (2001). Neutrophil apoptosis during the resolution of bovine mammary gland injury. Research in Veterinary Science, 70(1), 41-46. https://doi.org/10.1053/rvsc.2000.0440

Sobti, R. C., \& Krishan, A. (Eds.). (2003). Advanced flow cytometry: applications in biological research. Springer Science \& Business Media.Thairu, Y., Nasir, I. A., \& Usman, Y. (2014). Laboratory perspective of gram staining and its significance in investigations of infectious diseases. Sub-Saharan African Journal of Medicine, 1(4), 168-174. https://doi.org/10.4103/2384-5147.144725// Van Oostveldt, K., Vangroenweghe, F., Dosogne, H., \& Burvenich, C. (2001). Apoptosis and necrosis of blood and milk polymorphonuclear leukocytes in early and midlactating healthy cows. Veterinary Research,32(6), 617-622. https://doi.org/10.1051/vetres:2001143

Van Oostveldt, K., Paape, M. J., Dosogne, H., \& Burvenich, C. (2002). Effect of apoptosis on phagocytosis, respiratory burst and CD18 adhesion receptor expression of bovine neutrophils. Domestic Animal Endocrinology, 22(1), 37-50 https://doi.org/10.1016/S0739-7240(01)00115-1

Vissio C, Bouman M, Larriestra AJ (2018). Milking machine and udder health management factors associated with bulk milk somatic cell count in Uruguayan herds. Prev. Vet. Med. https://doi.org/10.1016/j.prevetmed.2017.12.011 